\title{
Grazing effects of two freshwater snails on juvenile Fucus vesiculosus in the Baltic Sea
}

\author{
Torleif Malm ${ }^{1,2, *}$, Roland Engkvist ${ }^{2,3}$, Lena Kautsky ${ }^{1}$ \\ ${ }^{1}$ Department oí Botany, University of Stockholm, 10961 Stockholm, Sweden \\ ${ }^{2}$ Department of Science, Kalmar University, 39129 Kalmar, Sweden \\ ${ }^{3}$ Department of System Ecology, University of Stockholm, 10961 Stockholm, Sweden
}

\begin{abstract}
The low salinity in the non-tidal Baltic Sea excludes many species, including marine littorinoids. The only large gastropods that occur in substantial quantities in the central Baltic proper are the freshwater snails Lymnaea peregra (O.F. Müller) and Theodoxus fluviatilis (L.); both are known to consume filamentous green and brown algae. The main objective of the present study was to test the hypothesis that freshwater snails can exert substantial grazing pressure on juvenile and regenerating Fucus vesiculosus populations in the Baltic Sea. In laboratory experiments, both snail species were able to graze on $F$. vesiculosus germlings up to a size of approximately 0.8 to $1.0 \mathrm{~mm}$. During the study period (autumn 1996 and spring and summer 1997), the largest $F$. vesiculosus germlings of the cohorts settled in September and May reached approximately $1.0 \mathrm{~mm}$ at the same time (July). Thus, to reach the 'safe' size and escape grazing requires about 8 mo for germlings settling in autumn but only 1 mo for germlings settling in spring. The survival and growth rate of new fronds from regenerating $F$. vesiculosus holdfasts in outdoor tank experiments were higher than for sexually recruited juveniles. After $1 \mathrm{yr}, 95 \%$ of the holdfasts had survived, and the mean length $( \pm \mathrm{SE}$ ) of the largest frond on each holdfast was $12 \pm 2 \mathrm{~mm}$. Grazing by $L$. peregra or T. fluviatilis did not affect regeneration or frond growth. During a long-term field study (1991 to 1994), an average of $8.5 \pm 0.7 \mathrm{~T}$. fluviatilis ind. $\mathrm{dm}^{-2}$ were found, with a maximum density of 40 ind. $\mathrm{dm}^{-2}$ in September. During a 1 yr study (1996), the average density of $L$. peregra was comparatively low and varied from 0.5 ind. $\mathrm{dm}^{-2}$ in April to 20 ind. $\mathrm{dm}^{-2}$ in August. The higher density found in August ( $L$. peregra) and in September ( $T$. fluviatilis) suggests that both species may have a grazing impact during this time. We conclude that both $T$. fluviatilis and $L$. peregra have the capacity to graze on zygotes and germlings of $F$. vesiculosus until they reach a safe size of approximately 0.8 to $1.0 \mathrm{~mm}$. Both snail species can occasionally reach abundances high enough to affect the recruitment of $F$. vesiculosus. Freshwater snails do not affect the regeneration from holdfasts. However, because the time for germlings settled in autumn to reach a safe size is much longer than for germlings settled in spring, it is possible that even a low snail density has an impact on recruitment in the field. This will, however, require verification because levels of grazing activity during different times of the year are unknown.
\end{abstract}

KEY WORDS: Growth rate $\cdot$ Herbivory $\cdot$ Lymnaea peregra $\cdot$ Theodoxus fluviatilis

\section{INTRODUCTION}

Several studies have shown that herbivory is an important biological factor affecting the mortality of young stages of fucoids in the marine environment (Vadas et al. 1992, Chapman 1995, Worm \& Chapman 1998). Periwinkles of the genus Littorina, for example, can, at high densities, substantially reduce Fucus vesi-

•E-mail: torleif.malm@ng.hik.se culosus germling populations (Lubchenco 1983), but once a $F$. vesiculosus juvenile becomes taller than $5 \mathrm{~cm}$, it is much less susceptible to grazing by littorinoids and limpets (Menge 1976, Lubchenco 1983). On the shores of Devon, in southern England, $F$. vesiculosus reached this size 6 mo after settling (Knight \& Parke 1950). According to Steneck \& Watling (1982), F. vesiculosus germlings have the same susceptibility to grazing by molluscs as filamentous green algae, but their resistance to grazing increases gradually as size 
increases. The increased size correlates to increased concentrations of the herbivore repellent phlorotannins (Denton et al. 1990). Thus, F. vesiculosus zygotes and germlings established on smooth rocks may be excluded by gastropod herbivores, but if crevices or barnacles are present, $F$. vesiculosus may be able to survive under low but not high grazing pressure (Lubchenco 1983). In the brackish Baltic Sea, marine limpets and littorinoid grazers are absent, and the only larger grazing gastropods that occur in substantial quantities on rocky shores are the freshwater snails Theodoxus fluviatilis (L.) and Lymnaea peregra. (O.F. Müller). Both species are known to consume green algae, cyanobacteria and diatoms (Skoog 1978), but nothing is known about their ability to graze $F$. vesiculosus zygotes and germlings.

Since Fucus vesiculosus may escape grazing by growth, their reproductive period and initial growth rate in relation to the dynamics of the animal populations are important for their survival (Menge 1976. Lubchenco 1983). The populations of grazing animals, (i.e. isopods, amphipods and gastropods) in the F. vesiculosus belts of the Baltic Sea vary considerably during the year, the highest abundances are in autumn and the lowest are in winter (Haage 1975, Anders \& Möller 1983). On the rocky shores of the North Atlantic Ocean, the reproduction of $F$ vesiculosus takes place from April to October, with a peak in June (Knight \& Parke 1950, Mathieson \& Guo 1992). In the Baltic Sea reproduction of $F$. vesiculosus occurs primarily from the end of May to the end of June (Bäck et al. 1990, 1991, 1993. Andersson et al. 1994). At Öresund, the inlet to the Baltic Sea, F. vesiculosus has 2 reproductive periods, 1 at the beginning of June and 1 in September (Carlson 1991). In Kalmar Sound, central Baltic proper, the $F$. vesiculosus populations on the west (mainland) side are reproductive during autumn, and the populations on the east side (Öland) are reproductive during spring and early summer (Malm et al. unpubl. data).

In addition to grazing, ice-scraping of the upper part of the algal belt is an important factor determining the population structure and distribution of Fucus vesiculosus in the Baltic Sea (Kiirikki \& Ruuskanen 1996). $F$. vesiculosus in the Baltic Sea may be found from 9 to $8 \mathrm{~m}$ depth, up to the water surface (Kautsky et al. 1986), but is pruned back during severe ice winters. In extreme cases, depending upon the amount of ice and intensity of the waves, the $F$ vesiculosus belts can be destroyed down to a depth of 4 to $5 \mathrm{~m}$ (Kiirikki \& Ruuskanen 1996). The holdfast of $F$. vesiculosus often survives ice-scraping, and the population may recover rapidly by vegetative regeneration (McCook \& Chapman 1993, Kiirikki \& Ruuskanen 1996j, but no studies on the growth rate of the new fronds and grazing on regenerating holdfasts have been conducted.
The aim of this work was to study the impact of the 2 most commonly occurring freshwater snails in the Baltic Sea, Lymnaea peregra and Theodoxus fluviatilis, on the survival of the Fucus vesiculosus recruits and regenerating fronds. Specifically we wanted to address the following questions: (1) Is grazing upon $F$. vesiculosus germlings prevented or reduced when sufficient size is attained, and, if so, what is the safe size? (2) Does germling mortality depend on snail density? (3) Are fronds regenerating from holdfasts vulnerable to grazing to the same degree as sexually recruited juveniles? (4) Are the field densities of $T$. fluviatilis and $L$. peregra high enough to affect the recruitment of $F$. vesiculosus? (5) How do growth rate, size-dependent mortality and snail densities interact to affect recruitment and survival of Baltic $F$. vesiculosus?

\section{MATERIALS AND METHODS}

Densities of Lymnaea peregra and Theodoxus fluviatilis were determined in 21 populations in 4 different areas along the east coast of Kalmar Sound between September 1991 and September 1994 (see Fig. 1). On each sampling occasion, the snails were collected and counted in 6 randomly placed $0.2 \times 0.2 \mathrm{~m}$ frames in the Fucus vesiculosus belt, at a depth of $1 \mathrm{~m}$ along a $100 \mathrm{~m}$ strip of the shore, and the total number per square meter was calculated. In addition, the abundance of the L. peregra and T. fluviatilis populations was measured every 14th day from April to December 1996 at Site 2, Area C (Fig. 1). The sampling design was the same as the method described above.

In order to follow the growth rate and mortality of Fucus vesiculosus juveniles over 1 yr, 200 granite plates, $2 \mathrm{~mm}$ thick and $35 \mathrm{~mm}$ in diameter, were seeded with $F$. vesiculosus zygotes in autumn (15 September to 15 October 1996) and in early summer (20 May to 25 June 1997) under natural light conditions. To seed the granite plates, they were placed on the bottom of an outdoor tank ( $2 \mathrm{~m}$ in diameter and $1 \mathrm{~m}$ deep). A net (mesh size $10 \mathrm{~mm}$ ), nailed to a frame, was placed $0.5 \mathrm{~m}$ above the bottom, and the tank was filled with seawater. Mature $F$. vesiculosus receptacles (male: female 1:2) were spread out in an even layer on top of the net. During the seeding periods, there was no water exchange in the tank, but after 1 mo, when the receptacles were removed, a flow of approximately $0.02 \mathrm{~m}^{3} \mathrm{~min}^{-1}$ was used. Small amounts of sediment and filamentous algae were washed from the plates at least once a week. The water in the tank had ambient temperature of $\pm 2^{\circ} \mathrm{C}$ and the salinity varied between 6 and 7 psu. During the period of the experiment (September 1996 to October 1997), the plates with F. vesi- 
culosus germlings were kept in the outdoor tank at the $1 \mathrm{~m}$ depth, except from December to April when the outdoor air temperatures were constantly below $-10^{\circ} \mathrm{C}$. During this period, they were stored in a temperature-controlled room in a $100 \mathrm{l}$ aquarium at $+5^{\circ} \mathrm{C}$ using light period equal to the actual day length (changed every week). The water in the aquarium was also changed once a week during this time. The intensity of light during this period and during all grazing experiments was approximately $50 \mu \mathrm{E} \mathrm{m}^{-2} \mathrm{~s}^{-1}$ and the fluorescent tubes emitted a spectrum close to natural sunlight.

To investigate the growth rate of the Fucus vesiculosus germlings, a total of 100 germlings from 10 granite plates were scraped off and photographed under a microscope on each sampling occasion. The lengths of the germlings were determined with the computer program NIH Image 1.61 (National Institute of Health). The change in average length of all germlings between 2 sampling occasions is the result of growth by larger individuals and mortality of mainly the smallest ones (Creed et al. 1996). To reduce the effect of size-dependent mortality (which is greatest in the small-size classes), the growth rate was calculated from the length increase of the tallest $10 \%$ of germlings. However, in September and October the length measurement was based on the whole cohort since the mortality rate decreased rapidly during late summer and autumn and few germlings were left on the plates.

The grazing experiments on germlings that settled in autumn 1996 were conducted at $+10^{\circ} \mathrm{C}$ and with the ambient day length $(15 \mathrm{~h}$ light in April and $16 \mathrm{~h}$ in August). One plate was taken from the tank and 3 snails were placed together in a $100 \mathrm{~mm}$ diameter petri dish for each replicate. In total, 15 Lymnaea peregra, 15 Theodoxus fluviatilis and 15 control replicates (without herbivores to account for natural mortality) were used in each experiment. The first experiment was performed from 10 April to 25 April 1997 and the second experiment, with a new set of plates, was performed from 26 July to 10 August 1997. The differences in plant mortality between the different treatments, i.e. T. fluviatilis and L. peregra and control, and periods, i.e. April and August, were tested with 2-way ANOVA and orthogonal contrasts, i.e. between the snails and control and between the 2 snail groups.

To investigate whether the snail-induced mortality of the germlings was size dependent, the lengths of the remaining germlings on all plates in the second experiment were measured. The length data of the surviving germlings in each treatment were divided into ten $0.2 \mathrm{~mm}$ size classes ranging from 0.2 to $2.0 \mathrm{~mm}$. The similarities between the frequencies were checked with the Kolmogorov-Smirnov (K-S) test.
In April/May 1998 the effect of snail grazing density on mortality of Fucus vesiculosus juveniles was studied using 100 granite plates seeded with $F$. vesiculosus zygotes in September 1997 (as described above). The grazing experiment was conducted at constant temperature $\left(+15^{\circ} \mathrm{C}\right)$ and with a $15 \mathrm{~h}$ day length. The temperature was increased by $5^{\circ} \mathrm{C}$ compared with the experiments in 1997 to better simulate the conditions in the sea during late spring and early autumn. One plate with $F$. vesiculosus germlings in a $100 \mathrm{~mm}$ diameter petri dish was used in each replicate. Seven series with 5 replicates in each series were performed. Three densities of each species, i.e. 1, 3, and 5 Lymnaea peregra and Theodoxus fluviatilis per petri dish, respectively, and 1 control without grazers were used. Water was changed in the dishes twrice a week. The differences in plant mortality between the different treatments, i.e. T. fluviatilis and $L$. peregra and control, and periods, i.e. April and August, were tested with 2-way ANOVA and orthogonal contrast.

Fifty germlings which had been detached from the plates by Theodoxus fluviatilis in the second grazing experiment (July/August 1997) were laid on a granite plate in a petri dish to investigate if they could reattach. The experiment was performed over 1 mo at $+10^{\circ} \mathrm{C}$ and $16 \mathrm{~h}$ day length.

To study the growth rate of fronds regenerating from holdfasts, 150 stones with 1 Fucus vesiculosus plant on each were collected from 10 different sites along the Kalmar Sound. The plants were cut leaving $0.5 \mathrm{~mm}$ of the holdfast. From 1 October 1996 to 20 October 1997 , all stones were stored in an outdoor tank with a water flow of roughly $0.02 \mathrm{~m}^{3} \mathrm{~min}^{-1}$. From December to April, the water flow was stopped and $30 \mathrm{~cm}$ thick ice was allowed to cover the tank. The length of the longest regenerating frond from each holdfast was measured on 5 June and 20 October 1997.

Grazing effects on regenerating Fucus vesiculosus fronds were studied using slices of stone with one $0.5 \mathrm{~mm}$ thick $F$, vesiculosus holdfast per slice. The slices were cut from stones with a diamond stone saw. One stone slice, $600 \mathrm{~mm}^{2}$ large, and 5 snails were placed in a $100 \mathrm{~mm}$ diameter petri dish for each replicate. In total, 10 Lymnaea peregra, 10 Theodoxus fluviatilis and 10 controls without snails were used. The experiment was conducted from 2 October to 10 November 1997 at a constant temperature $\left(+10^{\circ} \mathrm{C}\right)$ with a 12 h day length. Water was changed once a week.

For all analyses of data, Statistica ${ }^{\text {TM }} 4.1$ (StatSoft Inc.) was used. The homogeneity of variances was tested with Cochran's test, normality was tested with Goodness-of-Fit. Throughout the text and in the figures, the standard error has been used as the unit of variability. 


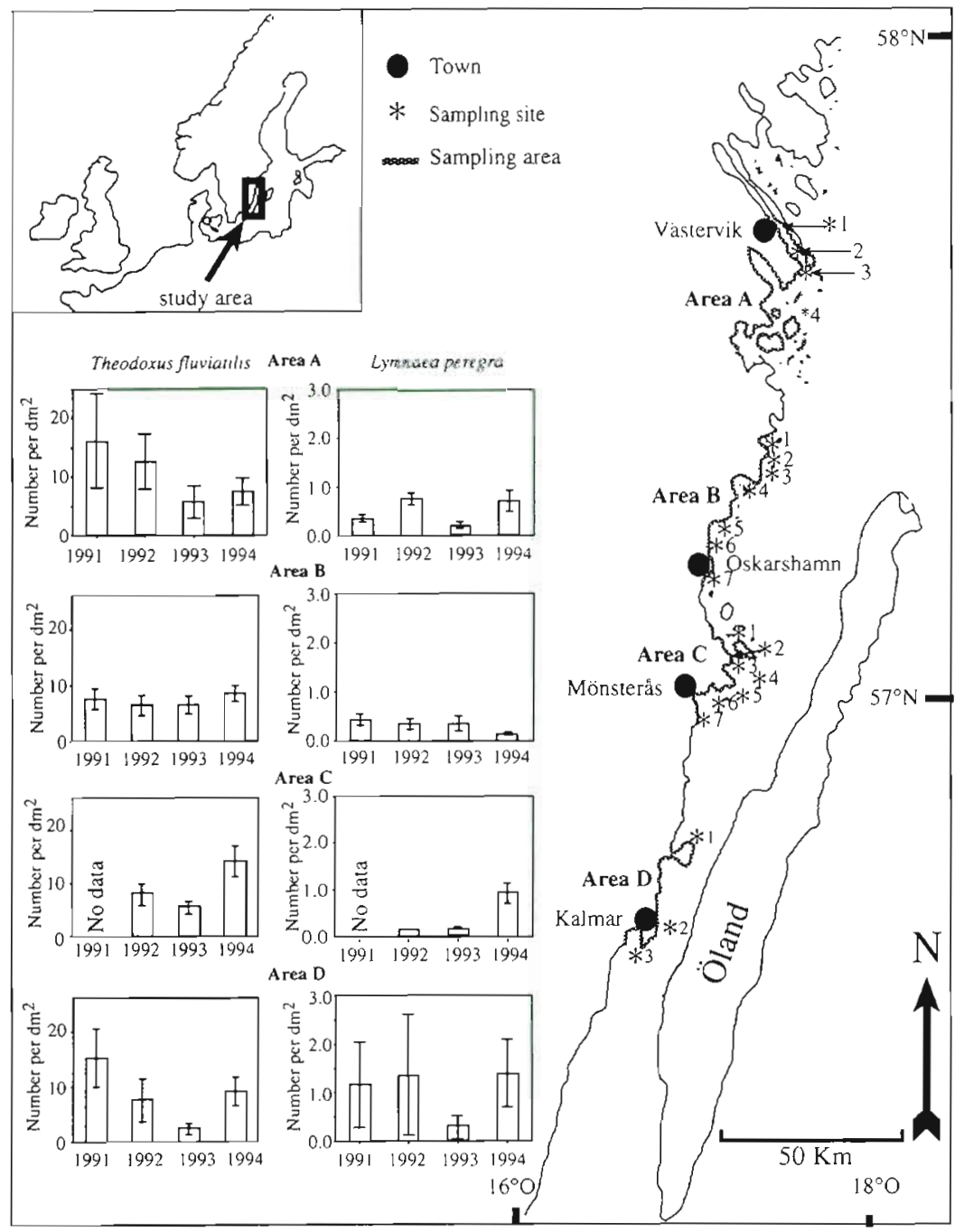

Fig. 1. Theodoxus fluviatilis and Lymnaea peregra. Field density (ind $\mathrm{dm}^{-2}$ ) in September during the years 1991 to 1994 in 4 areas (A, B, C and D) in the Baltic Sea off the south-east coast of Sweden. Stars indicate sampling sites

Sites 2 and 3 . The variations in number of snails between the years were not different in the different areas, i.e. the interaction between year and area was not significant.

The abundance of Lymnaea peregra did not show any large variations in time or space, nor was the interaction between year and area significant. The highest abundances were found in Area $\mathrm{D}\left(1.1 \pm 0.3 \mathrm{ind} . \mathrm{dm}^{-2}\right)$ and the lowest $\left(0.3 \pm 0.1\right.$ ind. $\left.\mathrm{dm}^{-2}\right)$ in Area $B$. The highest density found at any site was 3.9 ind $\mathrm{dm}^{-2}$ in Area D at Site 3, in 1992.

In 1996 a detailed study of the changes in snail abundances was performed at Site 2, Area $C$, and the results are presented in Fig. 2. Theodoxus fluviatilis had a more even distribution over the year than did Lymnaea peregra. From March to midJuly, $T$ fluviatilis was the most common snail species at the study site, while from early August to mid-September, L. peregra dominated. The abundance of $T$. fluviatilis was $5.0 \pm$ 2.5 ind. $\mathrm{dm}^{-2}$ from March to October. The species number declined from 2.5 \pm 0.1 ind $\mathrm{dm}^{-2}$ at the end of October to $0.50 \pm 0.25$ ind $\mathrm{dm}^{-2}$ in December. The abundance of $L$. peregra was low, $0.60 \pm 0.50$ ind. $\mathrm{dm}^{-2}$, from March to July. From the end of July to the beginning of August, the abundance increased rapidly to $17 \pm 6.6$ ind. $\mathrm{dm}^{-2}$. In late August the abundance declined again but was still higher throughout the autumn than in the

\section{RESULTS}

Data from a long-term study of 21 Lymnaea peregra and Theodoxus fluviatilis populations in 4 different areas along the southeast coast of Sweden, and performed over 4 yr (September 1991 to September 1994) are presented in Fig. 1.

The abundance of Theodoxus fluviatilis was highly variable in time, with significant differences between the years (2-way ANOVA, $F_{3,46}=3.53, \mathrm{p}=0.02$, logtransformed values). The highest overall density of $T$. fluviatilis was found in 1991 (12 \pm 3 ind. $\left.\mathrm{dm}^{-2}\right)$ and the lowest in $1993\left(5 \pm 1\right.$ ind. $\left.\mathrm{dm}^{-2}\right)$. Generally, no large variations in $T$. fluviatilis abundance were found between the different areas, but in September 1991 extreme values of 40 ind. $\mathrm{dm}^{-2}$ were found in Area $A$, spring. The decline continued in early winter and by mid-December only $1 \pm 0.7$ ind. $\mathrm{dm}^{-2}$ were left.

The average germing density on the plates seeded in September and October 1996, grown at a $1 \mathrm{~m}$ depth in an outdoor tank with running water and at ambient temperature and light, was $584 \pm 50$ germlings $\mathrm{cm}^{-2}$ in March 1997 and only $2.5 \pm 3.0$ germlings $\mathrm{cm}^{-2}$ in the middle of July. At the beginning of September the density had declined to $0.6 \pm 0.3$ germlings $\mathrm{cm}^{-2}$. Thus, most of the observed mortality occurred during the period March to July. In September 1997, the germling density per $\mathrm{cm}^{2}$ was similar on the plates seeded in June 1997 and September 1996, i.e. $0.4 \pm 0.2$ and $0.6 \pm$ 0.3 germlings $\mathrm{cm}^{2}$, respectively.

The growth rate, calculated on the largest $10 \%$ of the germlings, is presented in Fig. 3 . The germlings 


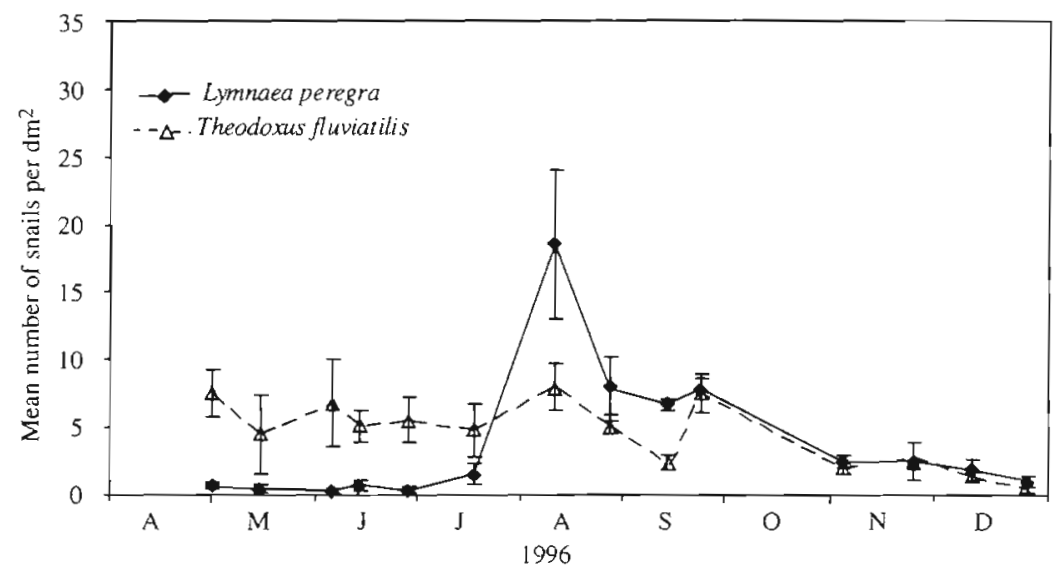

Fig. 2. Theodoxus fluviatilis and Lymnaea peregra. Changes in abundance $\pm \mathrm{SE}$ during 1996 at Site 2, Area C $\pm 0.1 \mathrm{~mm}$, i.e. significantly larger compared with the first experiment (1-way ANOVA, $F_{1.234}=592, \mathrm{p}<0.001$ ).

The overall Fucus vesiculosus germling density decreased significantly more in the experiment performed in April compared with the experiment performed in July/August (2-way ANOVA, $p<0.001$ ), and significant differences were found between the treatments (2-way ANOVA, $p<0.001$ ), but no interactions between the period and treatment $(2$-way ANOVA, $p=0.14)$. The germling density on plates grazed by the snails decreased more compared with the decrease on the control plates that settled during September and October 1996 showed almost no increase in average length during the following winter and early spring. Growth started in the beginning of May and by August 1997 the germlings had reached a mean length of $1.5 \pm 0.3 \mathrm{~mm}$. In October the average length of the autumn cohort was $4.0 \pm 1.6 \mathrm{~mm}$ (Fig. 3), which was similar to germlings settled in June 1997. The calculated growth rate for autumn-settled germlings was 0.01 and $0.04 \mathrm{~mm} \mathrm{~d}^{-1}$ during April to August and August to October, respectively. The mean growth rate of the spring-settled germlings was $0.02 \mathrm{~mm} \mathrm{~d}^{-1}$ during the study period (June to October).

The regeneration of Fucus vesiculosus fronds from cut holdfasts growing at $1 \mathrm{~m}$ depth was studied from 1 October 1996 to 20 October 1997 in an outdoor tank with running water. A high percentage of the holdfasts $(97.3 \%, n=150)$ had survived after $12 \mathrm{mo}$, and they had also produced new fronds. The growth rate of the regenerating fronds during the period September 1996 to June 1997 was $0.040 \pm 0.001 \mathrm{~mm} \mathrm{~d}^{-1}$, or 10 times faster than the growth rate of germlings during the same period of time. Between June and October the growth rate was $0.130 \pm 0.003 \mathrm{~mm} \mathrm{~d}^{-1}$, or 3 times faster than the germlings. Grazing by Lymnaea peregra and Theodoxus fluviatilis, respectively, was found to have no effect on the survival or the growth rate of the regenerating fronds. The survival of the holdfasts was $100 \%$ after $40 \mathrm{~d}$ grazing, and the growth rate of the fronds was $0.05 \pm 0.02 \mathrm{~mm} \mathrm{~d}^{-1}$, both in the control and on the stones grazed by $T$. fluviatilis or by $L$. peregra.

The impact of grazing by Lymnaea peregra and Theodoxus fluviatilis on Fucus vesiculosus germlings is presented in Figs. $4 \& 5$. At the beginning of the first experiment, run in April 1997 for $15 \mathrm{~d}$, the mean germling length was $0.20 \pm 0.05 \mathrm{~mm}$ and at the beginning of the second grazing experiment, run from June to August for $15 \mathrm{~d}$, the mean germling length was 0.63

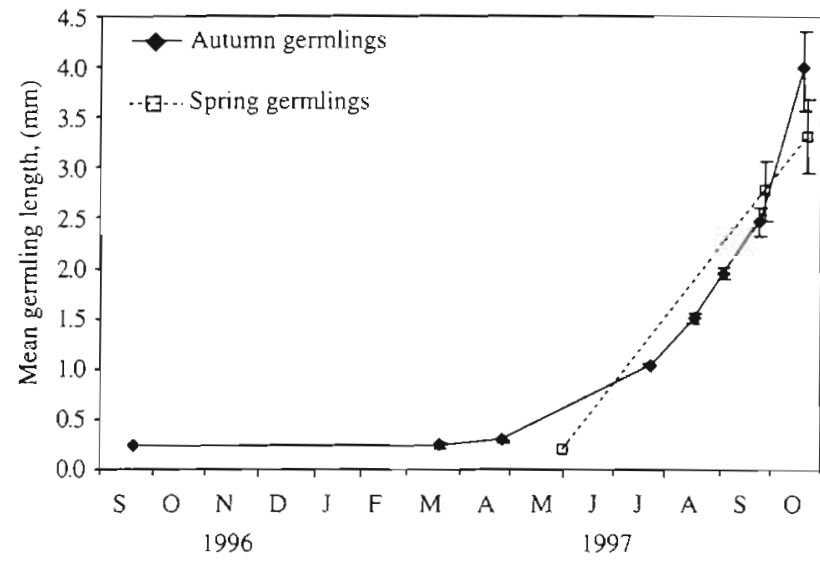

Fig. 3. Fucus vesiculosus. Average length increase \pm SE of autumn- and spring-germinated juveniles in 1996 and 1997. respectively. Grown in outdoor tanks at ambient temperature and light conditions except for December 1996 to April 1997 when they were kept indoors at $+5^{\circ} \mathrm{C}$

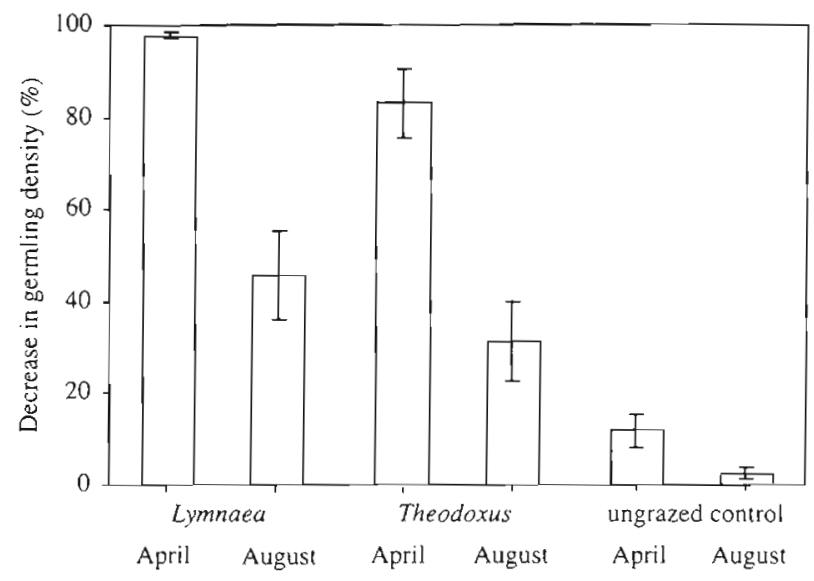

Fig. 4. Fucus vesiculosus. Average decrease in plant density \pm SE of autumn-germinated juveniles subjected to grazing by Theodoxus fluviatilis and Lymnaea peregra for $15 \mathrm{~d}$ in April and in August 1997, compared with ungrazed controls 


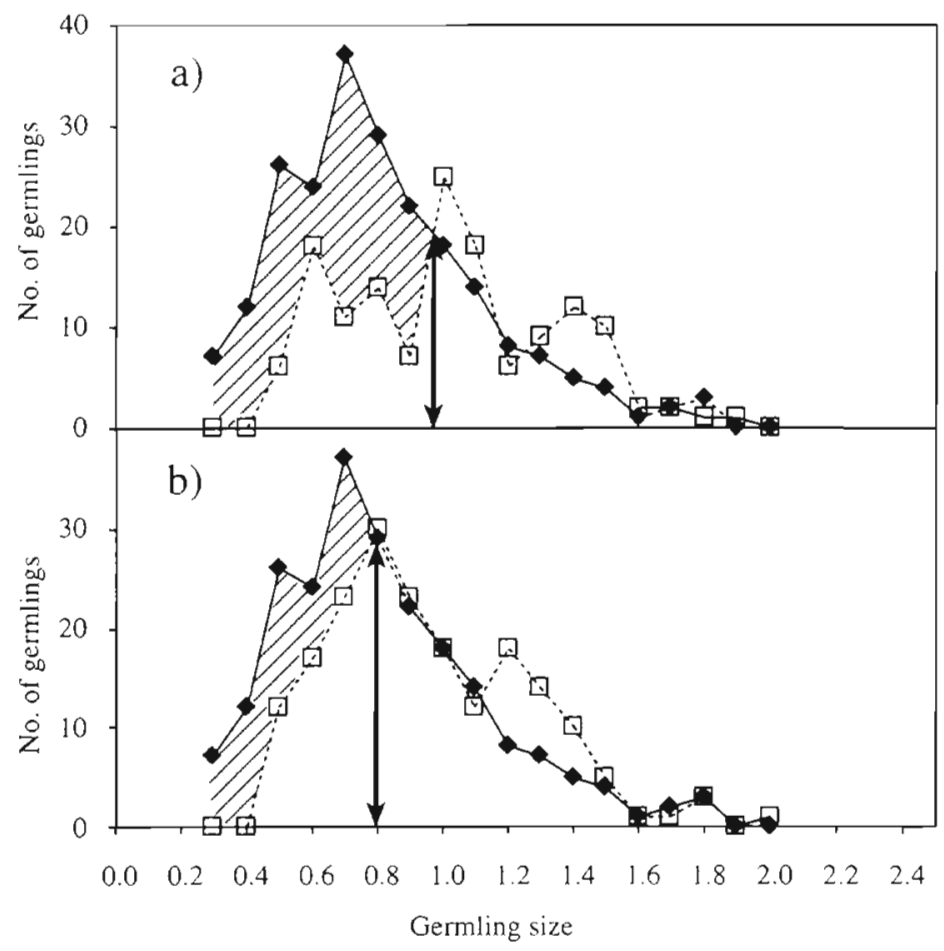

Fig. 5. Fucus vesiculosus. Frequency distribution of the germlings remaining on the ungrazed control plates $(-\downarrow)$ and the plates grazed by snails (--- ---): (a) Lymnaea peregra and (b) Theodoxus fluviatilis. Cross-hatched area indicates the size interval in which the germlings of the grazed plates are underrepresented and the arrow shows the limit of that area (determined by eye)

(Orthogonal contrast, $F_{1.184}=17.2, \mathrm{p}<0.001$ ), and on the plates grazed by Lymnaea peregra the germling density decreased more compared with the plates grazed by Theodoxus fluviatilis (Orthogonal contrast, $\left.F_{1,184}=84.5, \mathrm{p}<0.001\right)$

To test whether Theodoxus fluviatilis and Lymnaea peregra preferred to graze any particular size of the Fucus vesiculosus juveniles, the lengths of the $F$. vesiculosus germlings were measured at the end of the second grazing experiment. Total frequency distribution of the germlings after the second grazing experiment is presented in Fig. 5. The frequency distribution of the germlings that remained on the grazed plates was significantly different from the frequency distribution of the germlings on the ungrazed control plates, for both plates grazed by $L$. peregra (K-S test, $\mathrm{p}<0.001$ ) and and those grazed by $T$. fluviatilis (K-S test, $p<0.001)$. The frequency distribution of germlings on plates grazed by $L$. peregra was also significantly different compared with the frequency of germlings on plates grazed by $T$. fluviatilis ( $\mathrm{K}$-S test, $p<0.001$ ) On the plates grazed by $L$. peregra germlings smaller than $1.0 \mathrm{~mm}$ were underrepresented compared with the ungrazed control (Fig. 5a). and, on the plates grazed by $T$ fluviatilis, germlings smaller than $0.8 \mathrm{~mm}$ were underrepresented (Fig. 5b)

To test whether the abundance of Lymnaea peregra or Theodoxus fluviatilis is an important factor in the survival of the Fucus vesiculosus germlings, a grazing experiment on 6 mo old $F$. vesiculosus germlings was performed for 1 mo (20 April to 20 May 1998). The results are presented in Fig. 6. The mean length of the $F$. vesiculosus germlings on the ungrazed control plates was $0.25 \pm 0.06 \mathrm{~mm}$ at the beginning of the experiment. Again, a significantly larger decrease in $F$. vesiculosus germlings occurred on the plates which had been grazed by $L$. peregra compared with those which had been grazed by $T$. fluviatilis (2-way ANOVA, $p<0.001)$. There was also a significantly larger decrease in germlings on those plates which had been treated with 45 snails $\mathrm{dm}^{-2}$ compared with the other snail densities (Orthogonal contrast, $F_{1,24}=5.15, \mathrm{p}=$ 0.03). No interaction between species and density was found. Green algae had grown on the granite plates and the walls of the petri dishes by the end of the experiment, particularly in the petri dishes with the control plates and in the dishes with $L$. peregra, whereas in the petri dishes with $T$ fluviatilis no visible green algae were found.

All of the Theodoxus fluviatilis and Lymnaea peregra individuals used in all 3 grazing experiments survived the test period and produced faecal pellets throughout all experiments. Fucus vesiculosus cells found in the faecal pellets of $L$. peregra were empty, with just the cell walls remaining. However, in the T. fluviatilis faecal pellets, larger pieces of $F$. vesi-

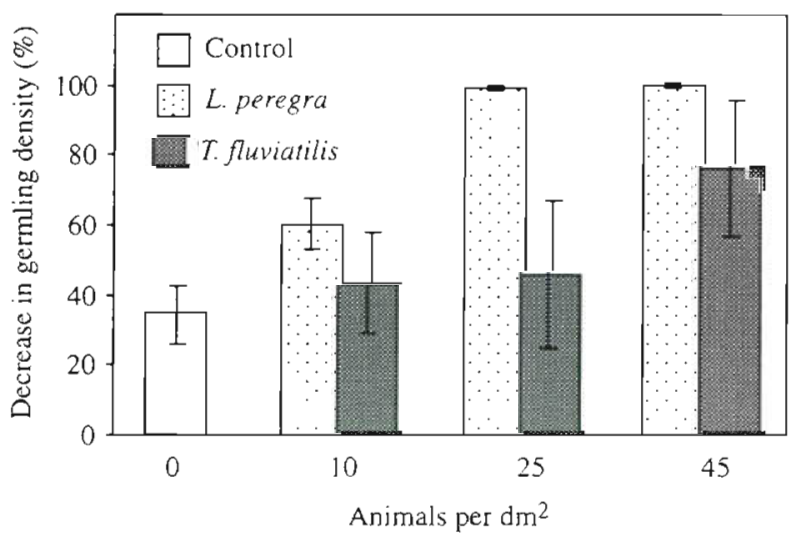

Fig. 6. Fucus vesiculosus. Average decrease in plant density \pm SE of autumn-germinated juveniles subjected to grazing by 3 different densities of Theodoxus fluviatilis and Lymnaed peregra during 1 mo from 20 April to 20 May 1998, compared with ungrazed controls 
culosus tissue, which had passed through the gut without being broken down, were observed. In addition, in the $T$. fluviatilis grazing experiments, many detached but intact germlings were found, the snails having pushed them away from the plates in their search for food. The detached germlings were not able to reattach, and they were all dead and had disappeared after 1 mo

\section{DISCUSSION}

This is the first time, to our knowledge, that the effects of grazing by freshwater snails on Baltic Fucus vesiculosus germlings have been investigated, whereas, in the marine environment, the impact of grazing by gastropods on Fucus spp. germlings has been closely studied (Lubchenco 1982, 1983, Janke 1990, Williams \& Seed 1992, Parker \& Chapman 1994, Chapman 1995, Worm \& Chapman 1998). The main factors that determine the impact of grazing snails are the time required for the germlings to reach sufficient size, and the amount of grazers and factors affecting grazing intensity (e.g. temperature and other food items).

The initial germling density in this experiment 600 zygotes $\mathrm{cm}^{-2}$ ) was similar to the estimated number of zygotes settled under a Baltic Fucus vesiculosus belt, 300 to $700 \mathrm{~cm}^{-2}$ (Serraõ et al. 1996). In the field, a number of mortality factors may affect the final survival of germlings, e.g. desiccation (Davison et al. 1993), grazing (Menge 1976, Lubchenco 1983), sedimentation (Shaffer \& Parks 1994), and shading or sweeping by adult plants (Lubchenco 1986). The most important causes of mortality were mainly eliminated in the tank where the growth experiments were conducted. However, the mortality was high $(99.9 \%)$, and only 0.5 to 1.0 juveniles $\mathrm{cm}^{-2}$ had survived on ungrazed plates after 1 yr. Similar mortality rates were estimated in the field by Gärding (1996) in the northern Baltic proper, i.e. $99 \%$ germling mortality in the first month. Thus the intraspecific competition may not have been larger in the experiment compared with the field.

Growth rate seems to be an essential factor in Fucus vesiculosus survival strategy against grazing (Lubchenco 1982). In our experiment in 1997, the largest germlings that settled both in autumn and in the following summer reached the same length, about $4 \mathrm{~mm}$, at the end of the growth season (Fig. 3). This is similar to observed $F$. vesiculosus germling growth rates in the field (L. Kautsky unpubl.). Temperature is known to regulate growth rate, and growth of $F$. vesiculosus in brackish water $(6 \%$ S) has been shown not to occur below $+10^{\circ} \mathrm{C}$ (Munda \& Kremer 1977). The water temperature in the growth experiments was below $+10^{\circ} \mathrm{C}$ from the beginning of October to the end of April, a
7 mo period. Thus, F. vesiculosus juveniles settled in September and October were exposed to temperatures high enough for growth only 1 mo longer than juveniles settled in June. This may explain the lack of difference in germling length between the 2 cohorts of juveniles at the end of the growth season (Fig. 3).

In the experiments performed in April 1997 and 1998, when the germlings were 0.2 to $0.3 \mathrm{~mm}$ tall, the mortality rate was much higher with grazers present than without. In April 1997 the mortality was 100\% on half of the grazed plates. The decrease in number of germlings was significantly less on the grazed plates in the grazing experiment performed in August when the germlings were larger $(0.5 \mathrm{~mm})$ compared with the grazing experiment performed in April. The relative size distribution after the second grazing experiment shows that the snails preferred the smallest germlings. This result also indicates that the period immediately following the zygotes' settling is critical for the survival of the germling, and that the probability of being grazed decreases rapidly as the germling's length increases.

The growth rate of fronds regenerating from holdfasts was 3 times faster than sexually recruited germlings. We suggest that the high growth rate exceeds the grazing capability of the snails: 40 out of 40 holdfasts both survived and produced new fronds, despite a high snail density of either Lymnaea peregra or Theodoxus fluviatilis.

Snail density is another important factor affecting the survival of Fucus vesiculosus germlings (Lubchenco 1983). The field abundances of Lymnaea peregra are, in most cases, far too low to be of any importance in affecting the recruitment of $F$. vesiculosus along the shores of southeastern Sweden. However, during a short period in August 1996, the abundance of L. peregra at Site 2, Area C (Fig. 2), reached 20 ind. $\mathrm{dm}^{-2}$, sufficient to drastically decrease the density of $F$. vesiculosus germlings (at least in the laboratory test), and, since most of the samples in the long-term investigation were taken in September, the highest abundances of $L$. peregra may have been missed. The abundances of Theodoxus fluviatilis may also be too low in most places to take any large share of the $F$. vesiculosus recruits, especially since the species seems to be a less-effective grazer on $F$. vesiculosus germlings than is $L$. peregra. Yet, in the northern part of the investigated area (Area A), T. fluviatilis occurred during 1991 at similar or even higher numbers than used in the experiments.

Our grazing experiments show that rather high abundances of either Theodoxus fluviatilis or Lymnaea peregra are needed to substantially affect the recruitment of Fucus vesiculosus. In the grazing experiments performed in April 1997 at $+10^{\circ} \mathrm{C}, 30$ ind. $\mathrm{m}^{-2}$ (L. pere 
gra or T. fluviatilis) were used. The impact on the juvenile $F$. vesiculosus recruits was dramatic; almost $100 \%$ of the germlings disappeared. At the same density of $T$. fluviatilis in May 1998 at $+15^{\circ} \mathrm{C}, F$ resiculosus juveniles of the same size and density were less affected than in April 1997. L. peregra consumed F. vesiculosus germlings in the experiment performed in May 1998 at a rate similar to that in April 1997. Thus, L. peregra seems to be a more efficient consumer of $F$. vesiculosus germlings than $T$. fluviatilis.

When the temperature was increased to $+15^{\circ} \mathrm{C}$, green algae were found growing on the granite plates and on the walls of the dishes with the control plates and in the dishes with Lymnaea peregra, but not in the dishes with Theodoxus fluviatilis. Filamentous green and brown algae, known to be the main food source of T. fluviatilis and L. peregra (Skoog 1978), are abundant on hard surfaces in shallow parts of the Baltic Sea, especially between March and the beginning of June. In September and October the biomass of filamentous algae is, however, significantly lower than in spring (Kiirikki 1996). This alternative food source might further reduce the impact of snail grazing on Fucus vesiculosus germlings in the field, especially during summer when filamentous green algae are abundant (Kiirikki 1996). Thus, grazing by freshwater snails could have a larger impact on $F$. vesiculosus germlings settled in autumn than on $F$. vesiculosus germlings settled in spring when there are abundant alternative food sources

Filamentous algae compete with juvenile Fucus vesiculosus by shading, by depleting nutrients and, probably the most important factor, by pre-empting space (Menge 1976, Lubchenco 1983. Hawkins et al. 1992). On the shores of the Atlantic Ocean, a substantial number of snails are necessary to prevent the filamentous algae from eliminating the fucoids (Lubchenco 1983). In the Baltic Sea, the snail population on the rocky bottoms is low in spring and probably cannot exert sufficiently high grazing pressure on the filamentous algae to open up space for $F$. vesiculosus germlings to settle. F. vesiculosus is known to be reproductive during spring in the Baltic proper (Andersson et al.1994), whereas in the study area on the mainland side of Kalmar Sound, F. vesiculosus reproduces exclusively during autumn, with a peak in the beginning of October (Malm et al. unpubl. data). There is also more free space for $F$. vesiculosus to settle on during the autumn compared to spring (Malm pers. obs.). Thus, we suggest that grazing may be more important in limiting the recruitment of the $F$. vesiculosus populations along the Kalmar Sound than competition from filamentous algae. The slow growth will further expose the germlings to the grazers for a longer period. However, nothing is known about the grazing activity of snails during the long period of low temperature in late autumn to early spring.

The survival of Fucus vesiculosus germlings may be affected by differences in the local numbers of freshwater snails, the particular species, i.e. Lymnaea peregra or Theodoxus fluviatilis, and the time of establishment of a germling population as shown in this study, but also possibly by the surface structure and the type of bedrock (Malm et al. unpubl. data). In the Baltic Sea the grazing by snails at high densities thus may have an effect on germling survival, although the combined impact of other potential grazers, e.g. Idothea baltica, and Gammarus spp., with biotic and abiotic factors that act on the population structure of $F$. vesiculosus needs further investigation.

Acknowledgements. We thank Dr H. Kautsky, Dr L.-E. Persson, and 2 anonymous referees for valuable comments on earlier versions of the manuscript. We are grateful to the research engineers J. Nilson and S. Tobiason for help with field sampling, and Mrs T Kindström and Mrs L. Tysper for analysing the samples. Financial support was given by the Stockholm Centre for Marine Research (Malm PhD position), Swedish Environmental Protection Board (Kautsky), Kalmar University Research Foundation, Sodra Cell Pulp Mill Company, and the KK Foundation

\section{LITERATURE CITED}

Anders K, Müller H (1983) Seasonal fluctuations in macrobenthic fauna of the Fucus belt in Kiel Fjord (western Baltic Sea). Helgol Meeresunters 36(3):277-283

Andersson S, Kautsky L, Kalvas A (1994) Circadian and lunar gamete release in Fucus vesiculosus in the atidal Baltic Sea. Mar Ecol Prog Ser 110(2):195-201

Bäck S, Collins JCC, Russell G (1990) Reproductive biology of Baltic Fucus vesiculosus. Br Phycol J 25(1):84

Bäck S, Collins JC, Russell G (1991) Aspects of the reproductive biology of Fucus vesiculosus from the coast of SW Finland. Ophelia 34(2):129-141

Bäck S, Collins JC, Russell G (1993) Comparative reproductive biology of the Gulf of Finland and the Irish Sea Fucus vesiculosus. Sarsia 78(3-4):265-272

Carlson I. (1991) Seasonal variation in growth, reproduction and nitrogen content of Fucus vesiculosus L. in the Öresund, southern Sweden. Bot Mar 34(5):447-453

Chapman ARO (1995) Ecology of fucoid recruits: effects of grazing and hydrodynamic forces. In: Grassle JP, Kelsey A, Oates E, Snelgrove P (eds) Proceedings of the 23rd Benthic Ecology Meeting. Rutgers, the State University of New Jersey, New Brunswick (abstract)

Creed CJ, Norton AT, Harding PS (1996) The development of size structure in a young Fucus serratus population. Eur J Phycol 31:203-209

Davison RI, Johnson EL, Brawley HS (1993) Sublethal stress in the intertidal zone: tidal emersion inhibits photosynthesis and retards development in embryos of the brown alga Pelvetia fastigiata. Oecologia 96:483-492

Denton A, Chapman ARO, Markham J (1990) Size-specific concentrations of phlorotannins (anti-herbivore compounds) in three species of Fucus. Mar Ecol Prog Ser 63: $103-104$ 
Gärding E (1996) Effects of eutrophication and Cladophora on the survival of Fucus vesiculosus zygots in the Baltic Sea. Master thesis, University of Stockholm, Stockholm

Haage P (1975) Quantitative investigations of the Baltic Fucus belt macrofauna. 2. Quantitative seasonal fluctuations. Contr Askö Lab Univ Stock 9:1-88

Hawkins SJ, Hartnoll RG, Kain JM, Norton TA (1992) Plantanimal interactions on hard substrata in the north-east Atlantic. In: John DM, Hawkins SJ, Price JH (eds) Plantanimal interactions in the marine benthos. Clarendon Press, Oxford, p 1-32

Janke K (1990) Biological interactions and their role in community structure in the rocky intertidal of Helgoland (German Bight, North Sea). Helgol Meeresunters 44(2): $219-263$

Kautsky N, Kautsky H, Kautsky U, Waern M (1986) Decreased depth penetration of Fucus vesiculosus (L.) since the 1940's indicates eutrophication of the Baltic Sea. Mar Ecol Prog Ser 28(1):1-8

Kiirikki M (1996) Experimental evidence that Fucus vesiculosus (Phaeophyta) controls filamentous algae by means of the whiplash effect. Eur J Phycol 31:61-66

Kiirikki M, Ruuskanen A (1996) How does Fucus vesiculosus L. survive ice scraping? Bot Mar 39:133-139

Knight M, Parke M (1950) A biological study of Fucus vesiculosus and Fucus serratus. J Mar Biol Assoc UK 29:439-501

Lubchenco J (1982) Effects of grazers and algal competitors on fucoid colonisation in tide pools. J Phycol 18(4): $544-580$

Lubchenco J (1983) Littorina and Fucus: effects of herbivores, substratum heterogeneity, and plant escapes during succession. Ecology 64(5):1116-1123

Lubchenco J (1986) Relative importance of competition and predation: early colonization by seaweeds in New England. In: Diamond J, Case TJ (eds) Community ecology, Harper \& Row, New York, p 537-555

Mathieson AC, Guo Z (1992) Patterns of fucoid reproductive biomass allocation. Br Phycol J 27(3):271-292

Editorial responsibility: Otto Kinne (Editor),

Oldendorf/Luhe, Germany
McCook LJ, Chapman ARO (1993) Community succession following massive ice-scour on a rocky intertidal shore recruitment, competition, and predation during early, primary succession. Mar Ecol Prog Ser 115(4):565-575

Menge AB (1976) Organisation of the New England rocky intertidal community: role of predation, competition, and environmental heterogeneity. Ecol Monogr 46:355-393

Munda IM, Kremer BP (1977) Chemical composition, and physiological properties of fucoids under conditions of reduced salinity. Mar Biol 42\{1\}:9-15

Parker T, Chapman ARO (1994) Separating the grazing effects of periwinkles and amphipods on a seaweed community dominated by Fucus disticus. Ophelia 39:75-91

Serrāo E, Kautsky L, Brawley, SH (1996) Distributional success of the marine seaweed Fucus vesiculosus $\mathrm{L}$. in the brackish Baltic Sea correlates with osmotic capabilities of Baltic gametes. Oecologia 107:1-12

Shaffer JA, Parks DS (1994) Seasonal variations in and observations of landslide impacts on the algal composition of a Puget Sound nearshore kelp forest. Bot Mar 37(4):315-323

Skoog S (1978) Aspects on the biology and ecology of Theodoxus fluviatilis (L.) and Lymnaea peregra (O.F Müller) in the Northern Baltic. PhD thesis. University of Stockholm Stockholm

Steneck RS, Watling L (1982) Feeding capabilities and limitation of herbivorous molluscs, a functional group approach Mar Biol 68:299-319

Vadas RL, Johnson S, Norton IA (1992) Recruitment and mortality of early post-settlement stages of benthic algae. $\mathrm{Br}$ Phycol J 27:331-351

Williams AG, Seed R (1992) Interactions between macrofaunal epiphytes and their host algae. In: John DM, Hawkins SJ, Price JH (eds) Plant-animal interactions in the marine benthos. Clarendon Press, Oxford, p 189-211

Worm B, Chapman ARO (1998) Relative effect of elevated grazing pressure and competition from a red algal turf on two post-settlement stages of Fucus evanecens C.Ag. J Exp Mar Biol Ecol 220:247-268

Submitted: September 23, 1998; Accepted: April 20, 1999 Proofs received from author(s): October 18, 1999 